University of Nebraska - Lincoln

DigitalCommons@University of Nebraska - Lincoln

Agricultural Research Magazine

U.S. Department of Agriculture: Agricultural

Research Service, Lincoln, Nebraska

$1-2002$

Detecting Stress in Animals

Sharon Durham

ARS, sharon.durham@ars.usda.gov

Ted $\mathrm{H}$. Elsasser

USDA-ARS, elsasser@anri.barc.usda.gov

Follow this and additional works at: https://digitalcommons.unl.edu/usdaagresmag

Part of the Agriculture Commons, Animal Sciences Commons, Food Science Commons, and the Plant Sciences Commons

Durham, Sharon and Elsasser, Ted H., "Detecting Stress in Animals" (2002). Agricultural Research Magazine. 93.

https://digitalcommons.unl.edu/usdaagresmag/93

This Article is brought to you for free and open access by the U.S. Department of Agriculture: Agricultural Research Service, Lincoln, Nebraska at DigitalCommons@University of Nebraska - Lincoln. It has been accepted for inclusion in Agricultural Research Magazine by an authorized administrator of DigitalCommons@University of Nebraska - Lincoln. 


\section{Detecting Stress in Animals}

W

hen people get stressed, they seek relief in many ways. Some exercise, some practice specific breathing techniques, and some eat chocolate. Farm animals become stressed, too. In domesticated food animals, stress can affect meat quality, milk production, and general health. But animal stress must often be intuited from clues such as lower-than-anticipated weights and increased illness.

Certain stressful events can be anticipated, for example, birth and weaning. But how do you know if an animal is stressed for some other reason? Ted H. Elsasser of ARS' Growth Biology Laboratory in Beltsville, Maryland, is investigating nitrated protein as a biomarker of stress. Nitrated proteins may serve as an early-warning system to point out an animal that may yield unsafe products or flag a need for therapeutic or intervention strategies to promote recovery from illness.

"The biggest problem for animal producers is disease management, so an early warning system would certainly be helpful," says Elsasser.

Other researchers have found that nitrated proteins are formed when certain components of proteins-tyrosinesbecome nitrated along critical parts of the regulatory pathway, altering the function of the proteins. This occurs after high levels of infectious stress, injury, or the presence of immune system hormones called inflammatory cytokines.

These changes in proteins occur in humans and other animals. But all nitrated proteins are not the same. Specific protein nitrations are associated with specific disorders, depending on the protein altered and the position of the alteration on the protein. Proteins are like jigsaw puzzle pieces that are designed to fit together. When proteins are altered, they no longer fit with other proteins, and they become ineffective. Different stresses are reflected in different biochemical systems of the body-resulting in different

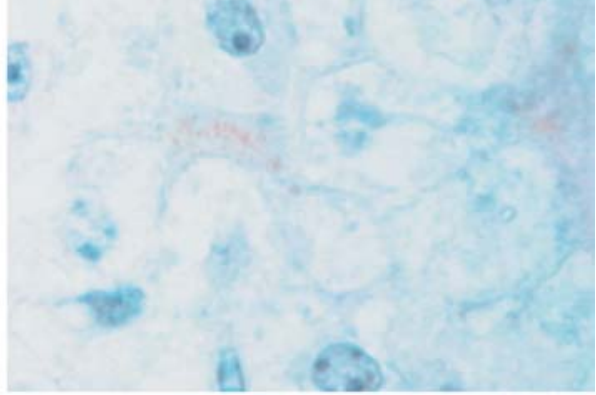

patterns and profiles of nitrated proteins. To complicate matters more, not all animals' biochemical pathways respond to the same stresses in the same way.

The protein nitrification process begins with arginine, an amino acid that is present in the diet and circulates in the bloodstream. If significant stress is present, more arginine is transported into cells by a specific transporter. This is one of the body's initial attempts to fight harmful consequences of stress.

Various biochemical pathways cause nitric oxide to be generated from the arginine. Depending on how cells have responded to stresses, their internal oxidative environment can change. Under some circumstances, the nitric oxide reacts with oxygen, creating a compound called peroxynitrite. It is this peroxynitrite that reacts with amino acids in proteins, tyrosines in particular, to form a nitrated protein.

Antioxidant compounds can control some of the processes through which peroxynitrite is formed. Just as we get vaccinations before foreign travel to ward off illness, Elsasser is investigating the possibility of preconditioning animals with antioxidants before predicted stresses to head off subsequent illness. Just as they mop up free radicals in the body, antioxidants combat some of the chemical reactions in cells that result in nitrated protein formation. It is important to note that nitrated proteins are not the same as free radicals.

Stress causes several undesirable effects, including slow animal growth and lowered immune response.
Above left:

Normal liver cells. Middle: The reddish-brown color indicates presence of nitrated proteins that developed in response to stress from bacterial toxin. Right: Pretreatment with vitamin $E$ appears to limit development of nitrated proteins.

Animal scientist Ted Elsasser prepares an injection of vitamin $E$ to test its ability to relieve some effects of bacterial toxins. 
Farmers often use small amounts of antibiotics to avert these effects. But sustained dosing can accelerate development of antibiotic-resistant bacteria, which may go on to infect humans. So Elsasser is investigating another method.

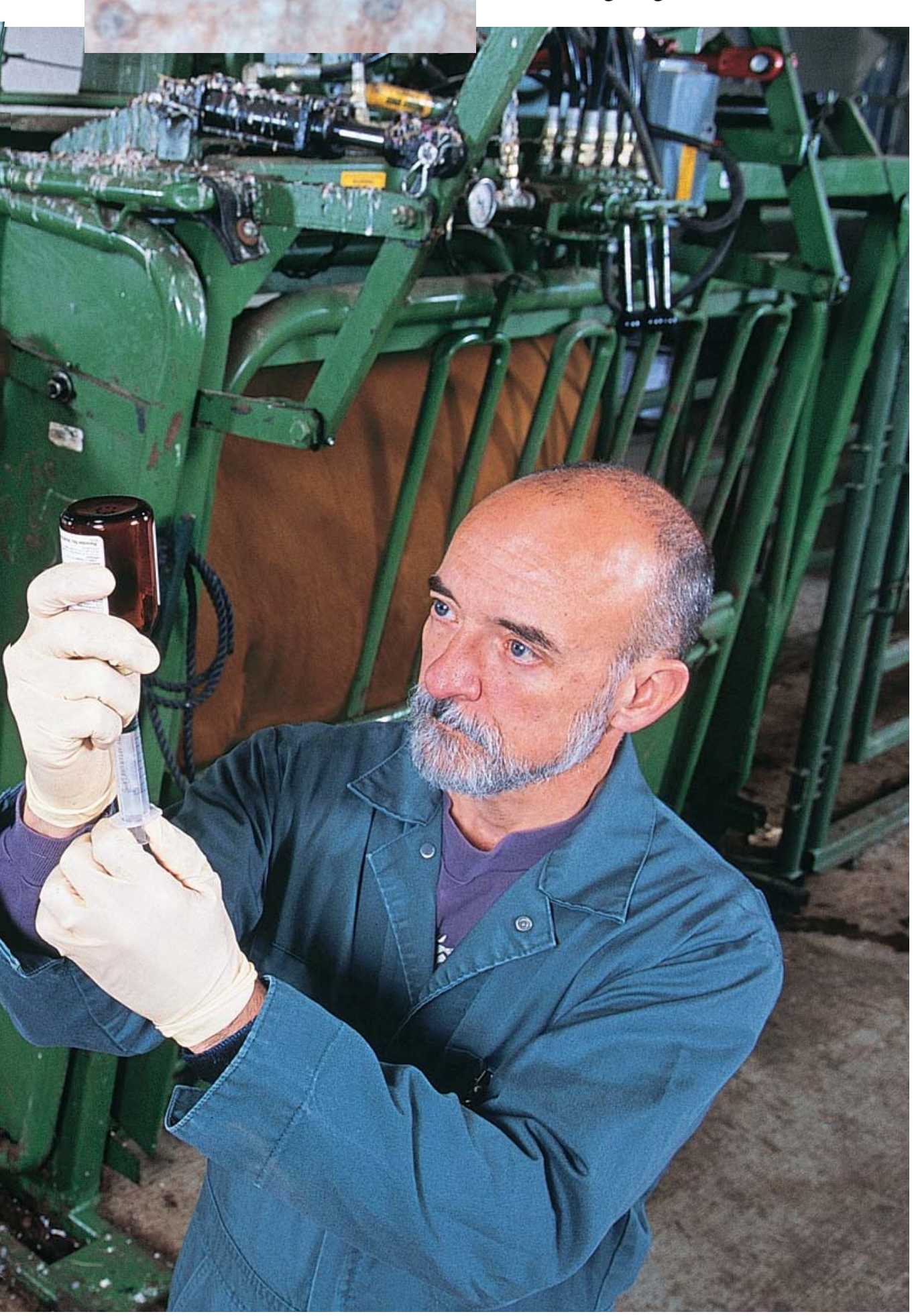

\section{An Alternative Approach}

Enter vitamin E, a standard antioxidant supplement in many people's nutritional regimen. "Our studies using vitamin $\mathrm{E}$ as a weapon against animal stress may offer some relief," says Elsasser. He gave six calves vitamin E as a pretreatment before challenging them with a toxin taken from bacterial cell walls. This toxin causes the immune system to react as if an infection were present. Elsasser also gave six calves only the toxin, and four received neither the toxin nor the vitamin E.

Compared to the four untreated calves, all the calves challenged with the toxin had significantly lower concentrations of IGF-I, a metabolic growth factor, in the liver and blood. However, those calves that were injected with toxin and pretreated with vitamin $\mathrm{E}$ had higher IGF-I concentrations than the calves that received only the toxin. The cattle given vitamin $\mathrm{E}$ also recovered more quickly from the systemic effects of the toxin. Pretreating with vitamin E could have significant benefits.

"Using vitamin $\mathrm{E}$ as a preconditioner allows us to maintain growth rates better and perhaps prevent secondary infections, which crop up when stress creates an opportunity for a pathogen to gain a competitive foothold," says Elsasser. Being able to prevent infections due to stress could lead to lower diseasemanagement costs, less antibiotic use, and healthier animals. And healthier animals mean that fewer disease-causing microbes make their way to human consumers.-By Sharon Durham, ARS.

This research is part of Food Animal Production, an ARS National Program (\#101) described on the World Wide Web at http://www.nps.ars.usda.gov.

Ted H. Elsasser is with the Growth Biology Laboratory, Bldg. 200, Room 210, 10300 Baltimore Ave., Beltsville, MD 20705; phone (301) 504-8281, fax (301) 504-8623,e-mail elsasser@anri. barc.usda.gov. 